> estimates of ultimately recoverable US oil reserves to his eventual winning model: an advanced calculation that incorporated past production, yield per foot of exploration and the tricky variable of reserve growth.

Inman does not, however, cite the work of UK economist William Stanley Jevons, whose 1865 warning about the economy's overreliance on coal prefigures the Hubbert story. Jevons died in 1882, so never saw his prediction come true: British coal output peaked in 1913. Hubbert, by contrast, was feted with numerous awards, including the Rockefeller Service Award in 1977, and broad coverage in The New York Times when his previous reports for the government and the USGS were acknowledged for their accuracy.

Hubbert's forecast was not the end of the US oil story. After his death, production continued to languish, in accordance with his forecast. But with fracking, the United States lifted oil production as recently as last year to levels close to the 1970 peak. Oil production is now falling again owing to a price bust - global supply capabilities were created for demand that failed to materialize. Inman does a fine job of handling this recent history.

The Oracle of Oil offers valuable insights beyond energy. In the demand-side bust of the 1930s, it shows Hubbert thinking deeply about the surplus of labour created partly, in his view, by the effects of powerful oil married to the newest machines: cars, construction equipment and aircraft. Hubbert was co-founder of Technocracy, a group of New York intellectuals aiming to prevent future economic dislocations. Two publications by keen observers of the low-growth problem Thomas Piketty's Capital in the Twenty-First Century (Seuil, 2013) and Robert Gordon's 2012 paper 'Is US Economic Growth Over?' (see go.nature.com/wblxig) - also explore this territory of limits and sustainability.

In Inman's work, the oilman emerges as a restless and prescient figure concerned with the environment. In writing the first biography of Hubbert, Inman has retrieved, if not rescued, the story of a scientist who has much to offer to today's energy conundrum.

Gregor Macdonald is a journalist based in Portland, Oregon, who covers the energy sector.

e-mail:gregor@gregor.us

\title{
NEUROSCIENCE
}

\section{Listening in on yourself}

\section{Douwe Draaisma is intrigued by a study examining both 'the voice within' and verbal auditory hallucinations.}

\section{$\mathrm{T}$} hinking about thinking is a curious exercise. Most of us probably agree that much of our own thought process takes the form of inner speech. But would we also agree that we hear an inner voice? If not, why would we call it talking at all? Can we experience and observe inner speech simultaneously, or would this be like "trying to turn up the gas quickly enough to see how the darkness looks", as US psychologist William James asked himself in 1890? Each of these questions may lead one into a philosophical forest, dense and dark.

Side-stepping such conceptual intricacies, psychologist Charles Fernyhough convincingly explores inner speech from a practical perspective. In The Voices Within, he discusses how people with aphasia (a speech and language disorder that stems from brain damage) may lose their sense of inner speech; how deaf people 'talk to themselves' (mostly in sign language, some by lipreading); how more than $60 \%$ of children have had silent conversations with imaginary friends; and whether people who stutter experience their inner speech as fluent (they do). Silent self-talk, evasive as it is to introspection, turns out to be a robust and quintessential part of memory, thought and imagination.

Fernyhough's sources are equally wideranging. He draws on internal monologues

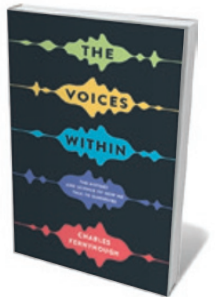

The Voices Within: The History and Science of How We Talk to Ourselves CHARLES FERNYHOUGH Profile: 2016.

in Gustave Flaubert's 1856 novel Madame Bovary and reports of self-talk by professional cricketers. He mentions physicist Richard Feynman having an argument with himself, and Joan of Arc insisting that God talked to her in French, not Latin. Today, Fernyhough directs Hearing the Voice, a research project at Durham University, UK, funded by biomedical charity the Wellcome Trust.

When I'm invited to write a review, I know from experience that it is wise to switch my inner speech from Dutch, my native language, to English, which I routinely use for scientific communication. Most bilingual people have no trouble identifying the language that they are thinking in. But I would be hard-pressed to say whether I talk to myself at a natural speed or in an abbreviated way, much less whether the stream of my thoughts flows equally fast (or slow) in both languages. Most people say that they have the definite impression that their inner speech unfolds faster than actual speech.

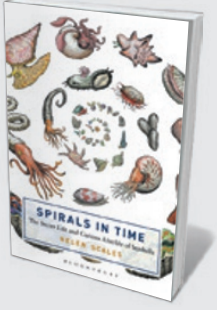

Spirals in Time: The Secret Life and Curious Afterlife of Seashells

Helen Scales (Bloomsbury, 2016)

From beachcombing to shipwreck diving, marine biologist Helen Scales shares her love of molluscs, many of which convert seawater into protective homes. Shells, she reveals, have served as everything from jewellery to calcareous currency.

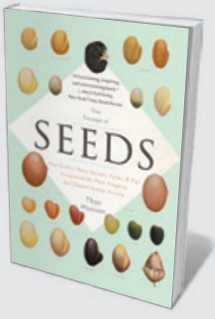

The Triumph of Seeds

Thor Hanson (Basic, 2016)

Biologist Thor Hanson sows the ultimate celebration of seeds and how they conquered Earth. Kernels can be crafty: unripe fruit, for instance, tastes bitter to deter predators from dispersing the seeds too soon (see Sandra Knapp's review: Nature 519, 288-289; 2015). 
